\title{
HUBUNGAN PENGETAHUAN, SIKAP DAN PERILAKU DALAM KESEDIAAN MENERIMA VAKSINASI COVID-19 PADA REMAJA $(<18$ TAHUN) DI DESA SUNGAI RAYA,KECAMATAN SUNGAI RAYA KABUPATEN KUBU RAYA PROV KALBAR 2021
}

\section{Windiyati $^{1}$, Fransiska Feby ${ }^{2}$}

\author{
Akademi Kebidanan Panca Bhakti Pontianak
}

Email Korespondensi : windiyati@gmail.com

\begin{abstract}
Abstrak
Coronavirus merupakan keluarga besar virus yang menyebabkan penyakit ringan sampai berat, seperti common cold atau pilek dan penyakit yang serius seperti MERS dan SARS. Tujuan penelitian ini adalah untuk mengetahui hubungan pengetahuan ,sikap dan perilaku remaja dalam menerima vaksinasi covid-19 di desa sungai raya,kecamatan sungai raya,kabupaten kuburaya. Provinsi Kalimantan barat. Tahun 2021. Metode penelitian ini menggunakan analitik korelasi dengan pendekatan cross sectional, dengan jumlah sampel sebanyak 129 orang remaja yang ada disesa sungai raya dengan mengambil responden di sekolah menengah umum kemala bhayangkari,sekolah menengah umum taman sungai raya dan Akademi Kebidanan Panca Bhakti Kubu Raya. Cara pengumpulan data menggunakan kuesioner terbuka dan tertutup serta analisis data menggunakan analisis dengan menggunakan uji statistic chi square dan keeratan hubungan dengan koefisien kontigensi. Hasil pengumpulan data terhadap 129 responden remaja di sekolah yang ada di desa sungai raya didapatkan sebagian dari responden 53 orang $(41,1 \%)$ berpengetahuan baik dan sebagian dari responden 71 orang $(55,5 \%)$ memiliki sikap mendukung dan sebagian dengan perilaku positip dan terdapat kesediaan menerima vaksinasi covid-19 dengan kesediaan tinggi yakni 51\% Hasil analisis bivariat didapatkan hasil bahwa ada hubungan pengetahuan dengan kesediaan $\mathrm{P}$ value 0,041, tidak ada hubungan sikap denagn kesediaan menerima $\mathrm{P}$ value-0,089 serta ada hubungan perilaku dengan kesediaan menerima vaksin Covid-19.Pvalue 0.03 di desa sungai raya,kecamatan sungai raya,kabupaten kuburaya. Provinsi Kalimantan barat. Tahun 2021.Dan hasil Analisis koefisien kontigensi terdapat hubungan keeratan rendah dengan kesediaan dengan Nilai C0,22C.Maks 0,81 ,hubungan perilaku dengan kesediaan mempunyai keeratan sedang dengan nilai C 0.18 C.Maks 0.70. Berdasarkan hasil dapat disimpulkan secara umum bahwa ada hubungan antara pengetahuan dengan kesediaan vaksinasi Covid-19 dan ada hubungan antara perilaku dengan kesediaan menerima vaksin.Hal ini dapat disimpulkan bahwa pengetahuan yang kurang dengan sikap yang tidak mendukung cenderung akan menolak atau ragu-ragu untuk divaksin Covid-19.pada remaja didesa sungai raya,kecamatan sungai raya,kabupaten kuburaya.Tahun 2021.perlu adanya kerjasama perangkat desa dengan tokoh masyarakat dan tokoh agama serta pihak sekolah untuk memberikan penyuluhan tentang pentingnya vaksinasi Covid-19.
\end{abstract}

Kata Kunci : Pengetahuan, sikap, perilaku.kesediaan Vaksinasi Covid-19

\begin{abstract}
Coronaviruses are a large family of viruses that cause mild to severe illnesses, such as common colds and serious illnesses such as MERS and SARS. The purpose of this study is to find out the influence of knowledge, attitudes and behavior of adolescents in receiving covid-19 vaccination in sungai raya villages, sungai raya subdistricts, kuburanaya districts. West Kalimantan province. In 2021. This research method uses correlation analytics with cross sectional approaches, with a sample number of

\footnotetext{
${ }^{1}$ Dosen Akademi Kebidanan Panca Bhakti Pontianak

${ }^{2}$ Mahasiswa Akademi Kebidanan Panca Bhakti Pontianak
} 
43 teenagers in the river by taking respondents at public high school kemala bhayangkari, public high school river park and pancabhakti obstetrics academy.kuburanaya. How to collect data using open and closed questionnaires and data analysis using univariate, bivariate and multivariate analysis using chi square statistical test.The results of data collection of 129 adolescent respondents in schools in sungai raya villages were obtained by some of the respondents $(41,1 \%)$ are well-informed and some of the respondents 71 people $(55 \%)$ have a supportive attitude and some with positive behavior and there is a willingness to accept covid-19 vaccination with a high willingness of $51 \%$. The results of bivariate analysis obtained the result that there is a relationship of knowledge with the willingness of $\mathrm{P}$ value ----,there is a relationship of attitude and willingness to accept $\mathrm{P}$ value----erta there is no behavioral relationship with willingness to receive the Covid-19 vaccine. in the village of sungai raya, sungai raya subdistrict, kuburanaya regency. West Kalimantan province. In 2021. Based on the results it can be concluded in general that there is a relationship between knowledge and the willingness of Covid-19 vaccination and there is a relationship between attitude and willingness to receive vaccines. It can be concluded that knowledge that is lacking with an unsanctioned attitude tends to refuse or hesitate to vaccinate Covid-19.in teenagers in the river raya, district of sungai raya, kuburanaya district. Year 2021 There needs to be cooperation of village devices with community leaders and religious leaders and schools to provide counseling on the importance of Covid-19 vaccination.

Keywords: Knowledge, Attitude, Behavior.Willingness To Vaccinate Covid-19

\section{Pendahuluan}

Virus Corona atau Covid 19 semakin marak di sejumlah negara, termasuk di Indonesia dan saat ini situasi dan kondisinya sudah menjadi pandemi, sehingga semua orang diharuskan mulai meningkatkan stamina dan menjaga daya tahan tubuh agar tidak mudah tertular covid 19 , tak terkecuali pada anak remaja.

Seperti negara-negara lain di seluruh dunia, wabah COVID-19 juga menjadi pandemic dan berkepanjangan berdampak signifikan pada sektor kesehatan dan perekonomian Indonesia.. Indonesia telah berupaya secara maksimal mengatasi tantangan-tantangan yang ada.

Virus Covid-19 ini tidak hanya menyerang pada orang dewasa dan lansia, tetapi juga pada anak-anak dan remaja. Penelitian ini juga didukung oleh Laporan Pusat Pengendalian Penyakit Amerika (CDC) menunjukkan bahwa anak-anak dan remaja lebih beresiko dan data pada bulan Februari sampai Juli 2020 didapatkan 70\% dari 121 kasus anak dan remaja yang meninggal karena penyakit Covid-19 berusia 10-20 tahun (Dhona dan Citra, 2020).

$$
\text { Upaya pemerintah untuk }
$$
menanggulangi kasus ini salah satunya adalah penyediaan vaksinasi Covid-19. Vaksin merupakan agen biologis yang memiliki respons imun terhadap antigen spesifik yang berasal dari pathogen penyakit menular. Vaksin sudah banyak digunakan untuk mencegah berbagai macam penyakit. Hal ini tidak menutup kemungkinan vaksin dapat digunakan untuk mencegah penyebaran Covid-19, penyakit yang sekarang sedang melanda dunia.

Remaja merupakan salah satu orang yang dapat membawa penyebaran virus Covid-19 dibanding kelompok usia lainnya. remaja merupakan kelompok rentan dan 
sangat sulit untuk dideteksi jika mengalami virus ini. Oleh karena itulah remaja juga perlu dilakukan vaksinasi. Vaksin diharapkan mampu menurunkan angka kematian dan penularan Covid-19 pada remaja. Namun karena kurangnya pengetahuan masyarakat tentang banyak isu negatif yang tersebar terkait vaksinasi, seperti masyarakat meragukan keamanan vaksin (30\%), keraguan terhadap efektivitas vaksin (22\%), ketidakpercayaan terhadap vaksin (13\%), kekhawatiran adanya efek samping seperti demam dan nyeri (12\%) dan alasan keagamaan $(8 \%)$. Sehingga membuat orang tua merasa takut untuk mengizinkan anaknya di vaksin, berdasarkan hal tersebut sangat penting pengetahuan tentang penyediaan vaksinasi. Vaksinasi adalah proses pemberian vaksin (antigen) melalui suntikan atau tetesan ke mulut. Hal ini dilakukan untuk meningkatkan produksi antibodi, guna menangkal virus/bakteri penyakit tertentu yang mungkin akan masuk ke tubuh (Arifianto, 2019).

Berdasarkan studi pendahuluan yang dilakukan pada Mahasiswa Akademi Kebidanan Panca Bhakti Pontianak dan anak sekolah menegah Bhayangkari serta anak sekolah menengah Taman Mulia yang usia rata -rata 12-18 tahun, ternyata masih ada anak yang kurang paham dan kurang mengetahui pengetahuan tentang vaksinasi pencegahan Covid-19 untuk remaja. Dan setelah peneliti memberikan penjelasan tentang vaksinasi Covid-19 ternyata ada beberapa anak remaja yang menolak dikarenakan takut efek samping dari penyuntikkan dan banyak mendengar isu bahwa setelah dilakukan penyuntikkan vaksin Covid-19 akan mengalami demam, pusing dan ada beberapa anak yang mengatakan bahwa orang tuanya tidak setuju jika dia di vaksinasi. Remaja juga merupakan salah satu orang yang dapat membawa penyebaran virus Covid-19 dirumah dibandingkan kelompok usia lain.

Dikarenakan banyak sekali sikap remaja yang kurang baik seperti tidak mematuhi protokol kesehatan dengan tidak memakai masker, menjaga jarak dan mencuci tangan dan remaja juga termaksud orang yang rentan tertular virus Covid-19 karena sering kali hampir tidak terdeteksi jika mengalami virus ini. Saat ini mahasiswa Akademi Kebidanan Panca Bhakti Pontianak yang sudah menerima vaksinasi Covid-19 ada 114 orang dan murid SMU Bhayangkari ada sebanyak 49 orang .dan Sekolah Menengah Umum Taman Mulia sebanyak 25 orang. Saat ini program vaksinasi sudah diberikan kepada remaja .

Dari hasil studi pendahuluan inilah yang melatarbelakangi peneliti ingin melakukan penelitian tentang pengaruh pengetahuan, sikap dan perilaku terhadap kesediaan penerimaan vaksinasi Covid-19 pada remaja usia <18 tahun dikabupaten Kuburaya khususnya di desa sungai raya,kecamatan sungai raya,Kabupaten Kubu Raya di mahasiswa Akademi Kebidanan Panca Bhakti Pontianak Kubu Raya dan murid Sekolah Menengah Umum Bhayangkari Kubu Raya serta Sekolah Menengah Umum Taman 
Mulia Kubu Raya Pontianak.Kalimantan

Barat Tahun 2021.

\section{Metode}

Desain Penelitian ini adalah Kuantitatif dengan Analitik Korelasi adalah teknis analisis data mengenai pengaruh atau hubungan antar dua variabel atau lebih dan peneliti juga menggunakan data kualitatif untuk kuesioner terbuka. Jumlah sampel dalam penelitian ini dihitung menggunakan rumus Raosoft (sample size calculator) dengan margin kesalahan 5\%, tingkat kepercayaan 95\%. Pada penelitian ini jumlah sampel yang didapat sebanyak 129 sampel. Dengan masing-masing Akbid pancabhakti 43 orang. SMU kemala Bhayangkari 43 orang dan SMU Taman mulia 43 orang.dengan sampel size calculator by raosolt. Dari perhitungan jumlah sampel menggunakan sample size calculator by raosoft didapat jumlah sampel minimal yang diambil dalam penelitian ini adalah 129 sampel. Pengambilan sampel dalam penelitian ini menggunakan teknik purposive sampling. Teknik metode sampling diperoleh melalui dengan pertimbangan kriteria tertentu.

\section{Hasil}

\section{Analisa Univariat}

Tabel 1. Distribusi Jenis Kelamin..

\begin{tabular}{lcc}
\hline \multirow{2}{*}{ Jenis kelamin } & \multicolumn{2}{c}{ Jumlah } \\
\cline { 2 - 3 } & $\mathbf{N}$ & $\mathbf{\%}$ \\
\hline Pria & 66 & 52 \\
wanita & 63 & 48 \\
Total & 129 & 100,0 \\
& & \\
\hline
\end{tabular}

Sebagian dari responden 67 orang (52\%) adalah pria dan sebagian dari responden 62 orang (48\%) adalah wanita.

Tabel 2 Distribusi Frekuensi Pengetahuan remaja Tentang Covid-19

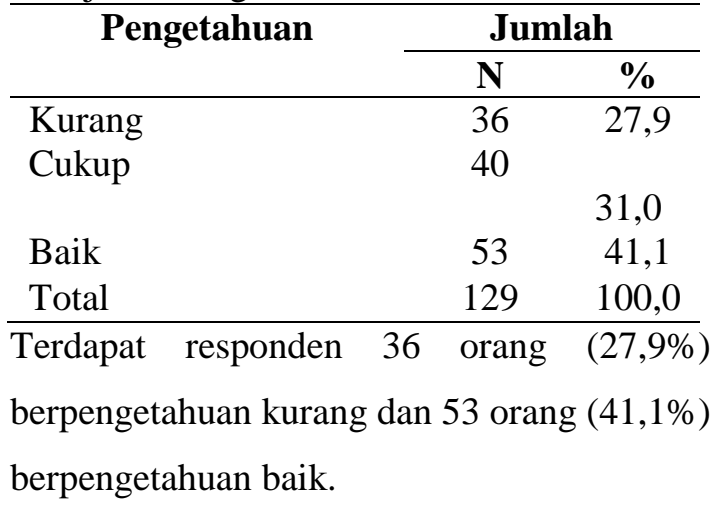

Tabel 3. Distibusi Frekuensi Sikap Remaja Tentang Vaksinasi Covid-19

\begin{tabular}{lcc}
\hline \multirow{1}{*}{ Sikap } & \multicolumn{2}{c}{ Jumlah } \\
\cline { 2 - 3 } & $\mathrm{N}$ & $\%$ \\
\hline Tidak Mendukung & 58 & 45 \\
Mendukung & 71 & 55 \\
Total & 129 & 100,0 \\
\hline Sebagian dari responden & 71 orang & $(55 \%)$ \\
memiliki sikap mendukung.
\end{tabular}

Tabel 4. Distibusi Frekuensi Perilaku Remaja Tentang Vaksinasi Covid-19

\begin{tabular}{|c|c|c|}
\hline \multirow{2}{*}{ Perilaku } & \multicolumn{2}{|c|}{ Jumlah } \\
\hline & $\mathrm{N}$ & $\%$ \\
\hline Positip & 66 & 51,1 \\
\hline Negatip & 63 & 48,9 \\
\hline Total & 129 & 100,0 \\
\hline \multicolumn{3}{|c|}{$\begin{array}{l}\text { Sebagian dari responden } 69 \text { orang }(53,4 \%) \\
\text { memiliki perilaku positip .Dan } 46,6 \% \text { yang } \\
\text { memiliki perilaku negatip. }\end{array}$} \\
\hline $\begin{array}{l}\text { Tabel 5. Distibusi } \\
\text { penerimaan Remaja } \\
\text { Covid-19 }\end{array}$ & $\begin{array}{l}\text { kuensi } \\
\text { k di }\end{array}$ & $\begin{array}{l}\text { kesediaan } \\
\text { Vaksinasi }\end{array}$ \\
\hline \multirow[t]{2}{*}{ Kesediaan } & \multicolumn{2}{|c|}{ Jumlah } \\
\hline & $\mathrm{N}$ & $\%$ \\
\hline Rendah & 77 & 59,6 \\
\hline Tinggi & 52 & 40,4 \\
\hline Total & 129 & 100,0 \\
\hline
\end{tabular}


Sebagian dari responden 77 orang $(59,6 \%)$

kesediaan rendah .Dan 40,4 \% dengan

kesediaan tinggi.

Kesediaan menerima vaksinasi Covid-19 juga dinilai melalui kuesioner terbuka. Peneliti menyimpulkan semua pendapat dari 129 responden didapatkan hasil:

1. Responden jumlah 47 orang yang bersedia mengatakan:

"Bersedia, karena saya ingin
menambah kekebalan tubuh agar tidak
tertular covid-19"

2. Responden jumlah 42 orang yang raguragu mengatakan :

"Bersedia sih,tapi ada rasa takut juga dengan vaksin .takut tidak halal, namun jika saya tidak di vaksin saya takut keluar rumah dan tidak dapat berkunjung dan bermain dengan teman.

3. Responden jumlah 40 orang tidak

"Tidak bersedia divaksin dengan alasan masih ragu-ragu dan saya takut karena ada efek samping dan orang tua saya juga tidak mengizinkan untuk divaksin"

\section{Analisa Bivariat}

Tabel 6. Hubungan Antara Pengetahuan Dengan Kesediaan penerimaan Vaksinasi Covid-19 Pada remaja( $\geq 18$ tahun) di desa Sungai raya. Kecamatan Sungai Raya

\begin{tabular}{|c|c|c|c|c|c|c|c|}
\hline \multirow{3}{*}{ Pengetahuan } & \multicolumn{4}{|c|}{ Kesediaan } & \multirow{2}{*}{\multicolumn{2}{|c|}{ Total }} & \multirow{3}{*}{$\underset{\text { Value }}{P}$} \\
\hline & \multicolumn{2}{|c|}{ Rendah } & \multicolumn{2}{|c|}{ Tinggi } & & & \\
\hline & $\mathrm{N}$ & 90 & $\mathrm{~N}$ & 56 & $\mathbf{N}$ & 96 & \\
\hline Kurang & 24 & 18.6 & 12 & 9,3 & 36 & 27,9 & \\
\hline Cuknp & 25 & 19,3 & 15 & 11,6 & 40 & 31,1 & 0001 \\
\hline Baik & 18 & 13,9 & 35 & 27,1 & 53 & 41,0 & 0,041 \\
\hline Total & 129 & 51,8 & 16 & 48,2 & 129 & 100 & \\
\hline
\end{tabular}

Sebanyak 24 responden yang tingkat pengetahuannya kurang terdapat dengan kesediaan menerima vaksin Covid -19 rendah dan 18 responden dengan pengetahuan baik dengan tingkat kesediaan tinggi yakni 35 orang .dengan nilai P.Value 0,041.dan $\mathrm{X}^{2}$ $=7,01$

Tabel 7. Hubungan Antara sikap Dengan Kesediaan penerimaan Vaksinasi Covid-19 Pada remaja ( $\geq 18$ tahun) di desa Sungai raya. Kecamatan Sungai Raya

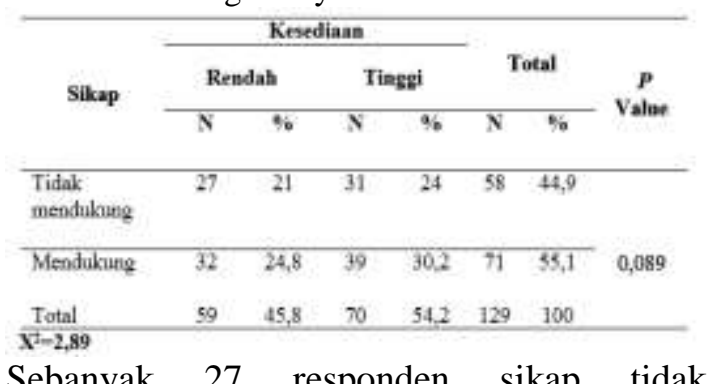

Sebanyak 27 responden sikap tidak mendukung terdapat dengan kesediaan menerima vaksin Covid -19 rendah dan 32 responden dengan sikap mendukung dengan tingkat kesediaan tinggi yakni 39 orang .dengan nilai P.Value 0,089. Dan $X^{2}=2,89$.

Tabel 8. Hubungan Antara Perilaku Dengan Kesediaan penerimaan Vaksinasi Covid-19 Pada remaja( $\geq 18$ tahun) di desa Sungai raya. Kecamatan Sungai Raya

\begin{tabular}{|c|c|c|c|c|c|c|c|}
\hline \multirow{3}{*}{ Perilaku } & \multicolumn{4}{|c|}{ Kesediaan } & \multirow{2}{*}{\multicolumn{2}{|c|}{ Total }} & \multirow{3}{*}{$\begin{array}{c}P \\
\text { Value }\end{array}$} \\
\hline & \multicolumn{2}{|c|}{ Rendah } & \multicolumn{2}{|c|}{ Tinggi } & & & \\
\hline & $\mathbf{N}$ & $\%$ & $\mathbf{N}$ & $\%$ & $N$ & $\%$ & \\
\hline Positip & 24 & 18.6 & 42 & 32,5 & 66 & 51,1 & \\
\hline Negatip & 46 & 35,7 & 17 & 13,2 & 63 & 48.9 & 0,03 \\
\hline Total & 70 & 54,3 & 59 & 45.7 & 129 & 100 & \\
\hline
\end{tabular}

Responden yang perilaku positip dengan kesediaan tinggi yakni 42 responden. Hasil uji chi square didapatkan Pvalue $0,03<0.05$ dan $\mathrm{X}^{2}=4,78$ yang berarti terdapat hubungan yang bermakna antara perilaku dengan dengan kesediaan menerima vaksin Covid-19. 
Tabel 9. Hubungan antara pengetahuan,sikap dan perilaku dengan kesediaan menerima vaksin Covid-19 Di Desa Sungai raya.Kecamatan Sungai Raya

\begin{tabular}{lccccc}
\hline Variabel & N & P.Value & $\mathbf{X}^{2}$ & $\begin{array}{c}\text { C } \\
\text { (Koefisiea } \\
\text { Kontingensi) }\end{array}$ & C mals \\
\hline Pengetahnan & 129 & 0,041 & 7,01 & 0,22 & 0,81 \\
\hline Sikap & 129 & 0,089 & 2,89 & 0,14 & 0,70 \\
\hline Perilaku & 129 & 0,03 & 4,78 & 0,18 & 0,70 \\
\hline
\end{tabular}

\section{Pembahasan}

a. Hubungan Pengetahuan Dengan Kesediaan

Vaksinasi Covid-19 Pada remaja didesa

Sungai raya Kabupaten Kubu Raya Tahun 2021.

Pengetahuan adalah hasil mengingat suatu hal, termasuk mengingat kembali kejadian yang pernah dialami baik secara sengaja maupun tidak sengaja dan ini terjadi setelah orang melakukan kontak atau pengamatan terhadap suatu objek tertentu (Mubarak, 2012).

Menurut Notoatmodjo (2007) dalam Lestari (2017) yang mengatakan bahwa semakin banyak informasi yang masuk semakin banyak pula pengetahuan yang didapat tentang kesehatan. Menurut Mubarak (2012), pengetahuan yang baik dapat mempengaruhi faktor seseorang seperti tingkat pendidikan, pekerjaan, umur, minat, pengalaman, kebudayaan lingkungan sekitar dan informasi. Pendidikan dan informasi yang cukup sangat berperan dalam peningkatan pengetahuan.

Berdasarkan hasil penelitian didapatkan bahwa sebagian dari responden 18 orang berpengetahuan baik dengan kesediaan tinggi sebanyak 35 orang, hal ini dapat disebabkan mereka sudah mengetahui informasi tentang Covid-19 baik melalui televisi, surat kabar maupun sosial media seperti instagram dan whatsApp dan terlebih lagi sudah ada website khusus informasi tentang Covid-19 mereka dapat mengaksesnya setiap saat. Apalagi di remaja sekarang sudah hampir semua mengetahui media sosial sehingga memudahkan dalam mengakses informasi.

Adapun beberapa faktor yang mempengaruhi penelitian ini sehingga ada hubungan antara pengetahuan dengan kesediaan menerima salah satunya adalah informasi dan kebudayaan lingkungan sekitar. Dimana pengetahuan yang kurang dengan kesediaan yang rendah dapat disebabkan responden mendapat informasi yang kurang tepat terkait Covid-19 salah satunya adalah penerimaan vaksinasi Covid19 banyak yang beranggapan jika kita menerima vaksinasi Covid-19 ini akan menyebabkan efek samping penyuntikan padahal sebenarnya penerimaan vaksinasi ini sangat baik dilakukan untuk memperkuat atau menambah kekebalan tubuh seseorang walaupun ada efek samping yang ditimbulkan tetapi itu merupakan hal yang wajar. Pemberian vaksinasi Covid-19 bertujuan untuk menambah lapisan pertahanan tubuh kita sehingga lebih baik dalam menghadapi wabah (Anies, 2020).

Penelitian sejalan yang dilakukan oleh Dhona Anggreni dan Citra pada tahun 2020 tentang hubungan pengetahuan remaja tentang Covid-19 dengan kepatuhan atau sikap dalam menerapkan protokol kesehatan, hasil penelitian menyatakan ada hubungan antara pengetahuan dengan sikap atau kepatuhan. Demikian juga dengan hasil 
penelitian ini dapat dilihat bahwa remaja memiliki pengetahuan yang lebih tinggi cenderung kesediaan menerima vaksinasi Covid-19 dibanding remaja yang memiliki pengetahuan yang rendah tingkat kesediaan menerima vaksin Covid-19 rendah.

b. Hubungan Sikap dengan kesediaan menerima vaksinasi Covid-19

Sikap seseorang dapat mempengaruhi tindakan. Tindakan adalah semua kegiatan atau aktivitas manusia, baik yang dapat diamati langsung, maupun yang tidak dapat dilihat dari pihak luar. Tindakan manusia seperti kesediaan menerima dengan ikhlas. Sikap merupakan suatu respon tertutup seseorang terhadap stimulus atau obyek tertentu yang sudah melibatkan faktor pendapat dan emosi yang bersangkutan. Faktor yang memegang peranan penting dalam menentukan sikap seseorang adalah pengetahuan. Tingkat pengetahuan yang baik dapat mempengaruhi seseorang dalam menentukan sikapnya terhadap suatu hal (Grishela dkk., 2020).

Hasil penelitian ini sejalan dengan penelitian yang dilakukan oleh Rachmani dkk. (2020), bahwa pengetahuan tentang COVID19 berhubungan dengan tindakan pencegahan COVID-19 (p value < 0,05) (Rachmani dkk., 2020).

Sikap negatip atau tidak mendukung dalam penerimaan terhadap vaksinasi Covid19 menjadi salah satu penyebab kurangnya peminat remaja untuk vaksinasi didesa Sungai Raya,selain tingkatan sikap remaja yang berada pada tingkat tidak mendukung dapat menjadi penyebab kurangnya peminat untuk kesediaan vaksinasi Covid-19.Berdasarkan hasil analisis ada sebagian remaja dengan sikap tidak mendukung dan tingkat kesediaannya rendah dan sebagian mendukung dengan tingkat kesediaan juga rendah.sedangkan remaja yang menyatakan tidak mendukung namun ada sebagian kecil remaja menyatakan kesediaannya di vaksinasi Covid-19 hal ini terlihat dari kuesioner terbuka yang dijawab responden.Hal ini membuktikan bahwa sikap positip seseorang tidak selalu berbanding lurus dengan tindakan seseorang.Hal ini sesuai dengan teori yang mengatakan bahwa sikap seseorang tidak selalu berbanding lurus dengan tindakan seseorang

Hasil penelitian ini sesuai dengan penelitian Yulliyanti 2020 di jakarta RS Gatot Soebroto didapatkan sebagian besar dari responden dalam kategori sikap tidak mendukung dengan tindakan bersedia dalam pencegahan Covid-19 untuk memakai masker dan hasil Analisis didapatkan P Value 0,49 > 0,05 yang bermakna tidak ada hubungan antara sikap dengan tindakan kesediaan.Dengan demikian dapat disimpulkan oleh peneliti bahwa tidak ada hubungan antara sikap dengan tindakan kesediaan menerima vaksinasi Covid19.didesa Sungai Raya .Kecamatan Sungai Raya.Kabupaten Kubu raya.

c. Hubungan perilaku dengan kesediaan menerima vaksinasi Covid-19

Dan dari penelitian ini dapat disimpulkan bahwa mayoritas remaja di desa sungai raya, Kecamatan sungai raya. Provinsi Kalimantan Barat memiliki perilaku yang positip dalam 
penerimaan vaksinasi Covid-19. Perilaku adalah respon individu terhadap suatu stimulus atau suatu tindakan yang dapat diamati dan mempunyai frekuensi spesifik, durasi dan tujuan baik disadari maupun tidak. Perilaku merupakan kumpulan berbagai faktor yang saling berinteraksi (Wawan, 2010).

Kesediaan didefinisikan sebagai keterbukaan individu terhadap peluang, yaitu kesediaan seseorang untuk melakukan suatu perilaku tertentu dalam situasi yang kondusif untuk menampilkan perilaku tersebut (Pomery et al., 2019). Dengan demikian, untuk menampilkan perilaku dalam menerima perilaku yang mengandung risiko ataupun yang tidak diharapkan secara sosialditentukan oleh sejauh mana seseorang memiliki kesediaan untuk menampilkan perilaku dalam pencegahan penyakit Covid19 dan kesediaan dalam menerima vaksinasi Covid-19.

Penelitian yang dilakukan oleh Zimmermann dan Sieverding (2010) menemukan bahwa kontrol perilaku yang dirasakan berkorelasi dengan kesediaan seseorang untuk bertindak, baik pada kelompok laki-laki maupun perempuan. Hasil analisis menunjukkan ada pengaruh perilaku terhadap kesediaan untuk bertindak agresif $(\beta=.18 ; p<.05)$, dan ada pengaruh kontrol perilaku yang dirasakan terhadap kesediaan untuk bertindak agresif $(\beta=.61 ; p<.01)$. Berdasarkan hasil tersebut, dapat disimpulkan bahwa individu yang memiliki perilaku yang positif dan memiliki keyakinan atas kemampuan sumber daya yang dibutuhkan untuk bertindak lebih cenderung menumbuhkan kesediaan untuk melakukan tindakan yang positip. Kontrol perilaku yang dirasakan memiliki kemampuan prediktif yang lebih kuat dibandingkan dengan sikap.

Menurut Philips J Vermonte Direktur Eksekutif CSIS Indonesia dalam konferensi pers yang digelar daring di Jakarta, "Sekitar 10 persen responden di DKI Jakarta dan 6,3 persen responden di Yogyakarta tidak percaya pada COVID-19, Dari segi usia, ketidakpercayaan pada vaksin dan penyebaran COVID-19 lebih tinggi pada Generasi Z yaitu usia 17-22 tahun dibanding kelompok usia lainnya.

Berdasarkan hasil uji statistik yang dilakukan tim peneliti CSIS dari hasil survei tersebut menunjukkan kurangnya kepercayaan masyarakat terhadap COVID-19 memengaruhi perilaku dalam penerapan protokol kesehatan, termasuk juga kepercayaan pada vaksin dan kesediaan mengikuti program vaksinasi. Survei menyebutkan hampir 40 persen responden di DKI Jakarta dan 27,5 persen responden di DIY mengaku tidak bersedia divaksin. Sebanyak 43 persen responden di DKI dan 31 persen responden di DIY mengaku belum yakin dengan kualitas vaksin. Ketidakpercayaan terhadap kemanjuran vaksin lebih tinggi di kalangan Generasi $\mathrm{Z}$ atau usia 17-22 tahun dibandingkan dengan kelompok usia lain. Uji statistik menunjukkan hubungan kuat antara perilaku terhadap penyebaran COVID-19 dengan kepercayaan terhadap vaksin dan kesediaan untuk divaksin. 
d. Hubungan pengetahuan.sikap dan perilaku dalam kesediaan menerima vaksinasi Covid-19.

Koefisien kontigensi yang terjadi antara tingkat pengetahuan dengan kesediaan remaja termasuk hubungan yang rendah tetapi pasti karena nilai koefisien kontigensi yang diperoleh antara 0,22 dan 0,81 Hubungan yang rendah antara pengetahuan dengan kesediaan dapat disebabkan karena tidak hanya dipengaruhi oleh pengetahuan saja. Akan tetapi banyak faktor yang dapat mempengaruhi pengetahuan seseorang, sehingga kemungkinan seseorang yang memiliki pengetahuan yang baik dapat menunjukkan sikap yang baik pula dan tidak menutup kemungkinan bahwa seseorang yang memiliki pengetahuan yang baik dapat menunjukkan sikap yang tidak baik. Demikian juga dengan hasil analisis Koefisien kontigensi yang antara sikap dengan kesediaan remaja termasuk hubungan yang rendah sekali bahkan dapat dikatakan tidak ada korelasi.hasil yang didapatkan $\mathrm{P}$ Value $0,089>0,05$ dan X2 hitung 2,89 $<2$ tabel 3,841 sehingga Ho diterima yang bearti tidak ada hubungan antara sikap dengan kesediaan .dan nilai koefisien kontigensi yang diperoleh antara 0,14 dan 0,70 yang bearti Hubungan yang rendah sekali bahkan dapat dikatakan tidak ada korelasi dengan nilai $\mathrm{C}=0,14$ dan C.Maks 0,70 denagn jarak yang terlalu jauh.

Hal ini sesuai dengan teori Notoatmodjo (2010) yang dipaparkan oleh Rachmani dkk. (2020), bahwa sikap merupakan reaksi seseorang terhadap suatu hal yang dipengaruhi oleh faktor pikiran, perasaan, dan perhatian karena berhubungan dengan setuju dan ketidaksetujuan terhadap suatu obyek (Rachmani dkk., 2020).

Hasil penelitian ini sejalan dengan hasil penelitian yang dilakukan oleh Rachmani dkk. (2020), bahwa terdapat hubungan yang signifikan antara pengetahuan tentang COVID-19 dengan sikap terhadap penanganan dan pencegahan COVID-19 ( $p<0,05)$ (Rachmani dkk., 2020).

Berdasarkan Tabel 5.9 dapat dilihat bahwa terdapat korelasi positif antara perilaku remaja dengan kesediaan menerima vaksinasi COVID-19 di desa sungai raya dengan koefisien kontigensi sebesar $\mathrm{C}=0,18$ dan $\mathrm{C}$, Maks $=0,70$. Hasil penelitian ini sesuai dengan teori yang dikemukakan oleh Thamaria (2016), bahwa perilaku atau perbuatan seseorang dapat diamati dan bahkan dapat dipelajari. Salah satu faktor yang mempengaruhi tindakan/perilaku adalah pengetahuan (knowledge). Tanpa pengetahuan seseorang tidak mempunyai dasar untuk mengambil keputusan dan menentukan perilaku terhadap masalah yang dihadapi (Thamaria, 2016).

Koefisien kontigensi yang terjadi antara perilaku dengan kesediaan remaja termasuk ke dalam hubungan yang rendah tetapi pasti karena nilai koefisien kontigensi yang diperoleh antara 0,18 dan 0,70 .Menurut peneliti, selain pengetahuan,sikap dan perilaku masih terdapat beberapa faktor yang mempengaruhi kesediaan seseorang sehingga seseorang yang memiliki pengetahuan dan sikap serta perilaku yang positip tentang COVID-19 belum tentu menunjukkan sikap 
dan tindakan/perilaku yang baik pula terhadap

kesediaan vaksinasi COVID-19.

Hasil penelitian ini sejalan dengan penelitian yang dilakukan oleh Irianto dkk. (2020) tentang pengetahuan, sikap, dan perilaku dalam pencegahan COVID-19 pada masyarakat di lampung.dengan hasil ada korelasi antara pengetahuan dan sikap dengan perilaku pencegahan penularan Covid-19.

Hal ini berarti bahwa sebagian remaja sebagai responden telah menunjukkan perilaku yang lebih baik dibandingkan sebagian lagi remaja dengan perilaku negatip..

\section{Kesimpulan}

Sebagian responden berpengetahuan baik yaitu 53 orang $(41,1 \%)$, dan sebagian responden mempunyai Sikap mendukung yakni 71 orang ( 55\%) dengan sebagian responden yakni 66 orang $(51,1 \%)$ mempunyai perilaku mendukung dalam vaksinasi Covid-19. Dari hasil Analisis didapatkan ada hubungan antara pengetahuan dengan kesediaan dengan $\mathrm{P}$ Value 0,041 dan $\mathrm{X} 2$ hitung 7,01. dan ada hubungan antara perilaku dengan kesediaan vaksinasi dengan $P$ Value 0,03 dan X2 hitung 4,78. serta tidak ada hubungan antara sikap dengan kesediaan dalam menerima vaksinasi Covid-19 dengan nilai P Value 0.089 dan X2 2,89. Hasil analisis koefisien kontigensi didapatkan pengetahuan mempunyai keeratan yang rendah dengan kesediaan $\mathrm{C}=0,22-0,81$.sedangkan Perilaku mempunyai hubungan keeratan sedang dengan kesediaan yakni 0,18-0,70 dan sikap tidak mempunyai keeratan hubungan atau hubungan rendah sekali .yakni 0,14-0.70

\section{Daftar Pustaka}

Abidin, A.Z., dan Errix, K.J. 2020. Hubungan Fungsi Pemeliharaan Kesehatan Keluarga Dengan Pencegahan Penularan COVID-19 Bagi Lansia di Desa Kandungrejo Baureno Bojonegoro. Jurnal Ilmu Keperawatan dan Komunitas.

Anggraeni, Dhona dan Citra Adityarini Safitri. 2020. Hubungan Pengetahuan Remaja Tentang Covid-19 Dengan Kepatuhan Dalam Menerapkan Protokol Kesehatan Dimasa Pandemi Tahun 2020. http://ejournal.stikesmajapahit.ac.id/index .php/HM/article/download/662/669. Diakses pada tanggal 15 Maret 2021 pukul 21.00 WIB.

Anies. 2020. Seluk Beluk Corona Virus. Jogjakarta: Arruzz Media.

Arifianto. 2019. Yakin dengan Vaksin dan Imunisasi. Jawa Barat: Kata Depan.

Azwar, S. 2011. Sikap Manusia Teori dan Pengukurannya. Edisi ke-2. Yogyakarta: Pustaka Pelajar. Halaman 15.

Didactic, Math. 2018. "Halaman Sampul." Math Didactic: Jurnal Pendidikan Matematika 4(3): 1-214. https://doi.org/10.33654/math.v4i3.272, Diakses pada tanggal 23 februari 2021 pukul 14.00 WIB.

Dinkes Kalbar. 2021. Dashboard Covid-19. https://dinkes.kalbarprov.go.id/covid-19/. Diakses pada tanggal 13 Maret 2021 pada pukul 14.00 WIB.

Grishela, V.V., Yennifer, H.K., Fawaid, A. 2020. Kajian Tingkat Pengetahuan COVID-19 terhadap Sikap dan Perilaku Pencegahan Penularan Infeksi COVID-19 pada Tenaga Kesehatan di Puskesmas Sungai Durian Tahun 2020. [online]. https://osf.io/w9z6y/. [diakses: 5 Mei 2021].

Http://corona.jakarta.go.id. Diakses pada tanggal 16 juni 2021. Pukul 19.00 WIB.

Irianto, Koes. 2015. Kesehatan Reproduksi. Bandung: Alfabeta. 
Kemenkes. 2021. Kesiapsiagaan Menghadapi Infeksi Covid-19. kemenkes. go.id/folder/view/full/structure=faq.html. Diakses pada tanggal 24 februari 2021 pada pukul 19.27 WIB.

Kemenkes. 2020. Pedoman Pecegahan dan Pengendalian Coronavirus Disease (COVID-29). Jakarta: Kementerian Kesehatan RI. Halaman 52.

Lestari, Ade Wina. 2017. Hubungan Pengetahuan Tentang Kesehatan Reproduksi Dengan Sikap TERHADAP Seks Bebas Pada Remaja DI SMA NEGERI 6 kendari. http://repository.poltekkeskdi.ac.id/347/1/ hubungan\%20pengetahuan\%20tentang\%2 0kesehatan\%20reproduksi\%20dengan $\% 2$ 0sikap\%20terhadap\%20seks\%20bebas\%2 0pada\%20remaja.pdf, diakses : 5 Mei 2021, 21:40 WIB.

Mubarak, Wahit Iqbal, dkk. 2012. Promosi Kesehatan Sebuah Pengantar Proses Belajar Mengajar Dalam Pendidikan. Yogyakarta : Graha Ilmu.

Ocky, Muhammad dan Iis. 2018. Virologi. Jakarta: Pustaka Jaya.

Pedoman Kesiap siagaan Menghadapi Corona Virus Disease (2020). Direktorat Jendral Pencegahan dan Pengendalian Penyakit

Pristiandaru, Danur Lambang. 2021.nasional. kompas.com $/ \mathrm{read} / 2021 / 02 / / 24 / 16154911 /$ update24februari-sebaran-7533-kasus-barucovid-19-di-jabar-terbanyak. Diakses pada tanggal 24 februari 2021 pada pukul 20.20 WIB.

Protokol Tatalaksasna Covid-19 (2020). Perhimpunan Dokter Paru Indonesia

Satgas COVID-19. Data Sebaran. [online]. https://covid19.go.id/. [diakses 03 Februari 2021].
Setiawan, A. 2017. Analisis Data Statistik. Jawa Tengah: Tisara Grafika.

Siswanto. 2014. Metode Penelitian Kombinasi Kualitatif-Kuantitatif Kedokteran Dan Kesehatan. Yogyakarta: Bursa Ilmu. Kuantitatif Kedokteran Dan Kesehatan. Jawa Tengah : Bossscript.

Sukaesih, dkk. 2020. Pengetahuan dan Sikap Mahasiswa Kesehatan Tentang Pencegahan Covid-19 Di Indonesia. https://ejr.stikesmuhkudus.ac.id/index.php jikk/article/download/835/53. Diakses pada tanggal 25 juni 2020 pada pukul 14.30 WIB.

Sugiono, 2015. Metode Penelitian Tindakan Komprehensif. Bandung: Alfabeta.

Suprobowati, Oky Dwi dan Iis Kurniati. 2018. Virologi. Jakarta: Pusat Pendidikan Sumber Daya Manusia Kesehatan.

Susila dan Surianto. 2014. Metodelogi Penelitian Cross Sectional. Klaten: Bossscript.

Www.covid.go.id. Diakses pada tanggal 14 juni 2021 pukul 13.00 WIB.

WHO. 2020. Transmisi SARS-Cov-2: Implikasi Terhadap Kewaspadaan Pencegahan Infeksi.

Yuwono, Podo dkk. 2020. Pengetahuan tentang Covid-19 pada Remaja Santri Payd Muhammadiyah pada Tahun 2020. httphttp://repository.urecol.org/index.php/ proceeding/article/download/1097/10.

Diakses pada tanggal 26 Februari 2021 pada Pukul 19.30 WIB. 